\title{
A MUNKAERÖ-PIACI INTEGRÁCIÓ HATÁSAI, KÜLÖNÖS TEKINTETTEL A MAGATARTÁS ÉS ÉLETMINŐSÉG VÁLTOZÁSAIRA
}

\section{Szerzők:}

Meisznerné Kuklek Noémi

Pécsi Tudományegyetem

Pusztafalvi Henriette

Pécsi Tudományegyetem

Egészségtudományi Kar

Egészségfejlesztési és Népegészségtani

Tanszék

Első szerző e-mail címe:

e-mail:noemi.kuklek@hotmail.com

\section{Lektorok:}

\author{
Barcsi Tamás \\ Pécsi Tudományegyetem \\ Egészségtudományi Kar \\ Egészségfejlesztési és Népegészségtani \\ Tanszék \\ Ágoston István \\ Pécsi Tudományegyetem \\ Egészségbiztosítási Intézet \\ Mező Ferenc \\ Eszterházy Károly Egyetem
}

Nemes Magdolna

Debreceni Egyetem

Meisznerné Kuklek Noémi, Pusztafalvi Henriette (2017): A munkaerő-piaci integráció hatásai, különös tekintettel a magatartás és életminőség változásaira. Különleges Bánásmód, III. évf. 2017/4. szám, 33-49. DOI 10.18458/KB.2017.4.33

\begin{abstract}
Absztrakt
A bemutatni kívánt program újszerüsége abban rejlik, hogy a mentális, szociális, vagy egészségügyi problémákkal küzdő álláskeresők számára nem csak a foglalkoztatás útján nyújt segítséget, hanem egy komplex, szolgáltatáscsomagot (munkaerő-piaci, szociális, egészségügyi szolgáltatás) is tartalmazó programmal, amely egyénre szabottan tud reagálni a fennálló nehézségekre, ezáltal javítva a résztvevő személyek életminőségét. Jelen tanulmány célja a foglalkoztatásba mentális, szociális vagy egészségügyi okból be nem vonható álláskeresők körében a speciális foglalkoztatási program bevonásának kezdetétől vizsgálni a magatartásbeli változásokat, valamint az életminőség javulását meghatározó tényezőket. Módszer: Vizsgálatunkban az általános jóllétet, megélhetéssel, anyagi háttérrel, családi háttérrel, egészségügyi, mentális problémákkal, munkavégzéshez kötődő problémákkal, szociális szolgáltatások igénybevételeivel, egészségügyi szolgáltatások igénybevételével kapcsolatos változásait monitoroztuk a program öt hónapja során, majd a kapott eredményeket kvantitatív és kvalitatív módszerekkel elemeztük. Következtetések: A jóllétnek mind a munkavállalók szubjektív érzelmi átéléseire, mind munkahelyi teljesítményükre,
\end{abstract}


munkahelyi magatartásukra pozitív hatása van, ezért a társadalomnak érdemes kiemelt figyelmet fordítania a munkáltatók érzékenyítésére, a komplex támogatási csomagot biztosító programok kialakítására, a munkavállalók életminőségének javulását meghatározó munkahelyi tényezők biztosítására. Az életminőség vizsgálatára irányultan eredményeink megerősítették, hogy megfelelő támogatással (pl. mentorálással, tanácsadással, támogató programok révén), növelhető a munkával, a munkahellyel való elégedettség, mely nemcsak az egyén, de a munkaadók, és a társadalom szempontjából is számtalan előnnyel jár: javul a munka minősége, a munkahelyi viselkedés és morál, kevesebb lesz a hiányzás, kisebb a betegségi és a fluktuációs ráta, nő a foglalkoztatottsági ráta.

Kulcsszavak: életminőség, munkaerő piaci szolgáltatások, szociális szolgáltatások, hátrányos helyzet

\title{
Diszciplína: egészségtudomány
}

\begin{abstract}
Effects of labor market integration, in particular changes in behavior and quality of life

The program you want to show is novel because it provides assistance to job seekers who face mental, social or health problems, it also provides a complex service package that includes labor market, social and health services. The program can respond individually to the existing difficulties, thus improving the quality of life of the participants. The aim of the study is to examine the factors that determine the behavioral changes and the quality of life quality among the jobseekers who can't be included in employment for mental, social or health reasons. Methods: In our study we monitored changes in general well-being, livelihoods, financial backgrounds, family backgrounds, health problems, work-related problems, social services, and healthcare services during the five months of the program, and analyzed the results obtained by quantitative and qualitative methods. Conclusion: Well-being has a positive effect on both the subjective emotional experiences of employees, their work performance and their workplace behavior. We think that society should pay attention to sensitizing employers, develop insurance programs for complex package of support, to ensure workplace factors influencing the improvement of the quality of life for workers' attention. The quality of life of our study confirmed that adequate support (mentoring, counseling, through programs supporting), to increase job satisfaction, workplace, which has many advantages in terms of not only the individual, but employers and society: improving the quality of work, the Workplace behavior and morale, less absenteeism, lower sickness and fluctuation rates, and employment rate increases.
\end{abstract}

Keywords: Quality of life, labor market services, social services, disadvantaged

Disciplines: health sciences

\section{BEVEZETŐ}

A 2016. július 1-én indult pilot speciális közfoglalkoztatási program célja, a foglalkoztatásba mentális, szociális vagy egészségügyi okból be nem vonható álláskeresők személyi körének feltárása, valamint a számukra nyújtható, személyre szabott szociális, egészségügyi és munkaerő piaci szolgáltatások, felzárkózást elősegítő képzések meghatározása az érintett személyek foglalkoztatásának, foglalkoztathatóságának növelése céljából. 


\section{Elözmények}

A Kormány általános célja a lehetőség szerinti, minél szélesebb körü, teljes foglalkoztatás megvalósítása. Ennek érdekében a jelenleg a közfoglalkoztatásba is nehezen bevonható személyek foglalkoztatását és foglalkoztathatóságát kívánja fejleszteni, hogy számukra a foglalkoztatás mellett munkaerö-piaci, szociális és egészségügyi szolgáltatásokat nyújt. A közfoglalkoztatás 2016.évi céljairól és a közfoglalkoztatás szempontjából kiemelt települések meghatározásáról szóló 1040/2016. (II.11.) Kormány határozat 2.d) ${ }^{\mathrm{i}}$ pontja a Belügyminisztérium, a Nemzetgazdasági Minisztérium, valamint a Nemzeti Fejlesztési Minisztérium számára határozott meg feladatot, mely szerint a tárcák feladata, hogy vizsgálják meg a foglalkoztatásba mentális, szociális vagy egészségügyi okból be nem vonható álláskeresők személyi körét, valamint a számukra nyújtható, személyre szabott szociális, egészségügyi és munkaerő piaci szolgáltatások, felzárkózást elősegítő képzések nyújtásának lehetőségét az érintett személyek foglalkoztatásának, foglalkoztathatóságának növelése céljából. A program megvalósítását két lépcsőben tervezték, melynek első fázisában a program hasznosságát, eredményességét tesztelik. Országos kiterjesztésre csak ennek tükrében, a tapasztalapok összegzését követően kerülhet sor. A program második lépcsőjét a befejezést követő időszak jelenti, melynek során a Belügyminisztérium, a Nemzetgazdasági Minisztérium és az Emberi Erőforrások Minisztériuma közös vizsgálatát követően, melyben vizsgálják a program tapasztalatait, eredményeit, értékelik azokat, majd ez alapján javaslatot tesznek a program folytatására vonatkozóan. A megvalósítási helyszínek, az úgynevezett közfoglalkoztatási pontok önkormányzatoknál történő létrehozásával a településen és a környezö településeken lévő hátrányos helyzetü személyek foglalkoztatása biztosíthatóvá válik. Ennek számos pozitív hatása van, úgymint nő az adott településen a foglalkoztatottak létszáma, helyben munkalehetőséget teremt, javítja a nehezen elhelyezhető személyek mentális, szociális helyzetét. http://www.kormány.hu ${ }^{i i}$ A beazonosított problémák alapján a munkavégzésre képes személyek a közfoglalkoztatási ponton végezhetnek az állapotuknak megfelelő egyszerü, rövid időn belül elsajátítható, betanított munkafeladatokat. (pl.: egyszerü összeszerelési tevékenység, csomagolás, textilipari, bőripari tevékenységek, dobozhajtogatás stb.).

\section{A program kezdete}

2016. június 7-én jelent meg a Nemzetgazdasági Minisztérium pályázati felhívása a foglalkoztatás elősegítéséről és munkanélküliek ellátásáról szóló 1991. évi IV. törvény 40.§iii_ a alapján, mely központi munkaerő-piaci program keretében speciális közfoglalkoztatási programhoz kapcsolódó munkaerö-piaci szolgáltatás támogatás nyújtására biztosít lehetőséget. A sajtóban még indulása előtt számos támadás célpontjává vált a pályázat, illetve a megvalósítandó program, ám mindezek ellenére a pályázat eredményekét 2016.július 1-én négy megyében indult el a megvalósítás: Baranya, Borsod-Abaúj-Zemplén, SzabolcsSzatmár-Bereg és Zala megyékben, mintegy háromszáz fővel. A kísérleti programban résztvevő települések kiválasztására a Belügy Minisztérium, az érintett járási és kormányhivatalok, valamint a települési önkormányzatok közös szakmai egyeztetése után került sor. A program az aktuálisan müködő önkormányzati nonprofit gazdasági társaságoknál, vagy települési önkormányzatoknál került megvalósításra. A program célja a mentális, szociális vagy egészségügyi okból foglalkoztatásba be nem vonható álláskeresők foglalkoztathatóságának növelése. A közvetlen célcsoportot a pályázati felhívás szerint a regisztrált álláskeresők alkották, akiknek legalább 40\%-os munkaképesség csökkenése van, minimum 24 hónapja, azaz tartósan álláskeresők, nyolc általános iskolai végzettséggel nem rendelkező, minimum három kiskorú gyermeket nevel vagy a családban legalább két fó regisztrált álláskereső van. Mivel a Zala megyében megvalósított programban vettem részt, a 
továbbiakban a Megyében megvalósításra került Pilot program tapasztalatait szeretném a továbbiakban összefoglalni.

\section{A kiválasztás folyamata}

A kiválasztott négy megye közül az egyik Zala Megye és ezen belül Nagykanizsa település kapta a lehetőséget a program megvalósítására. A Zala Megyei Kormányhivatal Nagykanizsai Járási Hivatal Foglalkoztatási Osztályának korábbi időszakból vezetett nyilvántartásából kerültek kiválasztásra a bevonandó személyek. A speciális közfoglalkoztatási programba meghatározott létszám két közfoglalkoztatási helyen 25, illetve 50 föt, azaz összesen 75 személyt jelentett. Azon ügyfelek kerültek megszólításra, akik tartósan (több mint 12 hónapja) az álláskeresői nyilvántartásba szerepeltek, nem volt közvetítési eseményük, vagy az rendszeresen sikertelen volt, foglalkoztatásuk folyamatosan meghiúsult, továbbá, a járási hivatal munkatársai által is ismert szociális, mentális, vagy egészségügyi problémával küzdenek. Az egészségügyi problémákat minden esetben hivatalos orvosi dokumentáció is alátámasztja.

A fent leírt szempontok alapján az első 2016.06.09.-2016.06.29. közötti időtartamban nyolc alkalommal történt behívás a helyi Foglalkoztatási Osztályra, melyet személyre szóló közvetítői beszélgetésre behívó levelet jutattak el az érintettek részére. A beszélgetésröl, csoportos tájékoztatókról feljegyzés, illetve jelenléti ív készült, melyben rögzítésre kerültek az ügyfél adatok, a tartós álláskeresés okai, a felkínált lehetőség vállalása illetve elutasítása. Az elutasítás esetén ezzel kapcsolatos indoklás.

A programba meghatározott létszám eléréséhez június, július és augusztus hónapokban is szükséges volt a behívások megszervezése. A három hónap során összesen 1025 fö került megszólításra, melyből 595 fö, azaz a megszólítottak 58\%-a jelent meg. A megjelentek közül a tájékoztatás során 327 fő nyilatkozta azt, hogy nem kíván részt venni a programban, míg 210 fó vállalta a foglalkoztatást. Összesen 103 fővel kötöttek a foglalkoztatók közfoglalkoztatási jogviszonyt azonban a foglalkoztatáshoz kapcsolódó orvosi alkalmassági vizsgálat során számos személyt egészségügyi szempontból alkalmatlannak találtak a speciális munkavégzésre is. A pályázatban elöírt 25 és 50 fös, a programba bevont és foglalkoztatásra került létszámot 2016 szeptemberében sikerült, mindkét foglalkoztatási helyszínen elérni. A fenti adatok tükrében megállapítható, hogy a speciális közfoglalkoztatás célcsoportját képező személyek esetében jelentős a visszautasítás, azaz a foglalkoztatástól való elzárkózás aránya. Azon személyek esetében, akik a megkeresés ellenére sem jelentek meg a tájékoztatón, illetve foglalkoztatás céljából a számukra kijelölt foglalkoztatási helyszínen (számuk 764 fö) szankciós intézkedések megtételére nem került sor, a továbbiakban is folyósították számukra a foglalkozást helyettesítő támogatást, illetve egyéb ellátásokat.

\section{A pilot programhoz kapcsolódó szolgáltatások}

A pilot program újszerüsége abban rejlik, hogy a mentális, szociális, vagy egészségügyi problémákkal küzdő álláskeresők számára nem csak a foglalkoztatás útján kíván segítséget nyújtani, hanem egy komplex, szolgáltatáscsomagot (munkaerő-piaci, szociális, egészségügyi szolgáltatás) is tartalmazó programmal, amely egyénre szabottan tud reagálni a fennálló nehézségekre.

Munkaerö-piaci szolgáltatások

A program megkezdésekor a munkaerő piaci szolgáltatások közül azon programelemek kerültek alkalmazásra, amelyek a munkára való felkészítést, a motivációt, a 
kulcskompetenciák fejlesztését célozták meg. A következő időszakban a foglalkoztatásra került a hangsúly, míg a program vége elött két-három hónappal az elhelyezkedést segítő munkaerő piaci szolgáltatások kerültek alkalmazásra. A program teljes időtartama alatt mentori szolgáltatás egészítette $\mathrm{ki}$ az egyénre szabott, egyéni igényekhez igazodó egészségügyi és szociális szolgáltatásokat.

\section{Mentori szolgáltatás}

A mentori szolgáltatás folyamatos, a programba vonástól a programból való kikerülést követő harminc napig tartott, mely magában foglalta a nyomon követést és utógondozást.

\section{Szociális szolgáltatások}

A szociális szolgáltatások közül a célcsoport számára az alábbiak értelmezhetők: A családsegítés a szociális vagy mentálhigiénés problémák, illetve egyéb krízishelyzet miatt segítségre szoruló személyek, családok számára az ilyen helyzethez vezető okok megelőzése, a krízishelyzet megszűntetése, valamint az életvezetési képesség megőrzése céljából nyújtott szolgáltatás. A munkaerő piaci, szociális és egészségügyi szolgáltatások háromoldalú megállapodásban kerültek rögzítésre. A három szerződő fél a szolgáltatást nyújtó, a közfoglalkoztató, valamint a megyei kormányhivatal.

Egészségügyi szolgáltatások

Szükség esetén az alábbi ellátások igénybevételét kell segíteni: Közösségi alapellátások: A közösségi ellátás a pszichiátriai, illetve a szenvedélybetegek részére nyújtott közösségi alapellátás, valamint a szenvedélybetegek részére nyújtott alacsonyküszöbü ellátást jelenti. Pszichiátriai-, szenvedélybetegek nappali ellátása. Egészségügyi szolgáltatások: Ha a programba bevonásra került személy egészségügyi vizsgálata, ellátása szükséges, a közfoglalkoztatott mentora a lakóhelye szerinti területi ellátási kötelezettséggel rendelkező egészségügyi szolgáltatóhoz (járóbeteg szakellátó, háziorvos) kell, hogy irányítsa, szükség esetén kísérje az ügyfelet. Vannak beutaló nélkül és beutalóval igénybe vehető ellátások.(Kötelező egészségbiztosítás ellátásairól szóló 1997. évi LXXXIII. törvény ${ }^{i v}$ végrehajtásáról szóló 217/1997. (XII.1.) Kormány rendelet `tartalmazza. Mentális probléma esetén pszichiátria vagy klinikai szakpszichológiai járóbeteg szakrendelésre, szenvedélybetegség probléma esetén az addiktológiai járóbeteg szakrendelésre, egyéb egészségügyi probléma esetén a választott háziorvoshoz vagy a területileg illetékes háziorvoshoz történő irányítás javasolt, ő tudja beutalni a megfelelő szakrendelésre, diagnosztikai vizsgálatra az ügyfelet. Amennyiben a járóbeteg szakrendelésen az ügyfél végleges ellátása nem oldható meg és állapota indokolja, a járóbeteg szakrendelés szakorvosa beutalja a területi ellátási kötelezettséggel rendelkező fekvőbeteg (aktív, rehabilitáció) szakellátást végző egészségügyi szolgáltatóhoz. A munkaerő piaci, szociális és egészségügyi szolgáltatások háromoldalú megállapodásban kerültek rögzítésre. A három szerződő fél a szolgáltatást nyújtó, a közfoglalkoztató, valamint a megyei kormányhivatal.

\section{A pályázatban kiírt szolgáltatások keretei}

A bevonási szakasz 2016.07.01.-2016.07.31-ig tartott. Ebben a szakaszban a Járási Hivatal foglalkoztatási osztálya az informatikai rendszerben lévő profiling besorolás szerinti harmadik kategóriába tartozó álláskeresőket szólítja meg, akik valamilyen okból az elmúlt egy évben nem vettek részt közfoglalkoztatásban, vagy egyéb munkaviszony/közfoglalkoztatási jogviszony létesítését elősegítő munkaerő-piaci tevékenységben. A megszólított álláskeresők csoportos tájékoztató formájában kaptak információt a speciális programban kapható segítségről és annak feltételeiről. A kiválasztott 
álláskeresőket a foglalkoztatási osztály munkatársa közvetítette a programba. A programba közvetítést követően foglalkozás-egészségügyi vizsgálatra szóló beutalót kapott az ügyfél. A foglalkozás-egészségügyi vizsgálat elvégzését követően annak eredményétől függően,- ha az egyén alkalmas minősítést kapott-bekerült a speciális programba (közvetítése sikeres). A foglalkoztatási szerv jelölte ki a megfelelö speciális közfoglalkoztatási pontot, ahol a foglalkoztatóval közfoglalkoztatási jogviszonyt létesített. Ebben az időszakban került kitöltésre az előzetes bevonás adatlapja, (Elözetes diagnózis pontozóskála) ahol egy részletes interjú keretében meghatározásra kerültek az álláskereső elhelyezkedését akadályozó problémák és ezek fő megoldási irányai. Figyelembe véve az álláskereső beszámolója alapján a szociális és egészségügyi területek szegmentálására vonatkozó észrevételeket. E szerint három fó terület a szociális, egészségügyi, és a munkaerő piaci problémák kerülhettek beazonosításra.

Személyeként a program ideje alatt legalább 5 egyéni tanácsadás és 2 csoportos foglalkozás biztosítását írta elő a program, az alábbi bontásban:

I. Bevonási szakaszban (2016. július 01. - 2016. július 31.): Minimálisan, egyénenként három egyéni tanácsadás, mely munkavállalási- rehabilitációs, pszichológiai tanácsadás nyújtását tette lehetővé.

II. Megvalósitási szakaszban (2016. augusztus 01. - október 31.): Minimálisan elöírt 2 csoportos foglalkozás, egyéni munkavállalási tanácsadás, pszichológiai tanácsadás, munkavállalói kulcsképességet, kulcskompetenciákat fejlesztő csoportos foglalkozás (4 napos), motivációs csoportos foglalkozás (5 napos), személyiségfejlesztést, beilleszkedést és önálló életvitelt segítő csoportos foglalkozás megtartását írta elő.

III. Befejezö szakaszban (2016. november 01. - november 30.): 2 egyéni tanácsadás, tanulási képességek és készségek vizsgálata, egyéni munkavállalási tanácsadás, egyéni álláskeresési tanácsadás, álláskeresési technikák (3 napos)

- valamint, a program ideje alatt a folyamatos mentori szolgáltatás biztosítását.

Utókövetés: 2016.12.01.-2016.12.31.-mentori utókövetés

A támogatott szolgáltatás időtartama: 2016. július 01. - 2016. november 30., azonban ezt harminc napos mentorálási folyamat egészíti ki az utókövetés érdekében 2016. december 31ig. A szolgáltató 2 fő teljes munkaidős munkavállalási tanácsadó, valamint 2 fő teljes munkaidős, mentori szolgáltatást biztosító személy munkaviszonyban vagy megbízási szerződéssel történő alkalmazásával 75 fő számára biztosította a szolgáltatását a program ideje alatt. A megvalósítás helyszínein 2-2 munkavezető végezte a munkafeladatok koordinálását. 1253/2016.(VI.6.) Kormány határozat ${ }^{\mathrm{vi}}$

\section{A pilot program speciális juttatásai}

A speciális közfoglalkoztatási program időtartama alatt a résztvevő közfoglalkoztatottak új típusú, speciális közfoglalkoztatási bérben részesültek, melynek összege alacsonyabb mértékü a jelenlegi közfoglalkoztatási bérnél. Tekintettel arra, hogy a célcsoport halmozott hátrányos helyzete miatt elsősorban nem gazdasági értelemben vett értékteremtő foglalkoztatás valósult meg, illetve nem elvárható tőlük olyan színvonalú és teljesítményü munkavégzés, ami a többi közfoglalkoztatottól, így bérezésüket ennek megfelelően, csökkentett, de a passzív segélyezéshez képest magasabb mértékü, napi hat órás munkavégzés mellett került kialakításra. A közfoglalkoztatási bér és a közfoglalkoztatási garantált bér megállapításáról 
szóló 170/2011.(VIII.24.) Kormány rendelet ${ }^{\mathrm{vii} a l a p j a ́ n ~ a ~ s p e c i a ́ l i s ~ k o ̈ z f o g l a l k o z t a t a ́ s i ~ b e ́ r ~ h a v i ~}$ 41.556 Ft-ban került megállapításra, a legalább középfokú iskolai végzettséget és szakképesítést igénylő munkakör betöltése esetén a közfoglalkoztatási pontok által indított speciális közfoglalkoztatási programban hat órában foglalkoztatottat megillető speciális garantált közfoglalkoztatási bér 53.277 Ft-ban került megállapításra. A munkabér mellett a programban résztvevők számára, napi egyszeri meleg étkezést, munkaruhát biztosítottak a foglalkoztatók a megvalósítás helyszínein.

\section{A tevékenységek}

Nagykanizsán, mint azt már írtam két helyszínen került megvalósításra a program 25 , illetve 50 fös keretszámmal. Mindkét helyszínen a munkafolyamatok egyszerü, rövid időn belül elsajátítható munkafeladatokat jelentettek, hiszen a mintaprogram „elsősorban értékteremtő, hasznos, a helyi sajátosságokon alapuló, a település önfenntartását elősegítő tevékenységet" támogatta.(375/2010.(XII.31.) Korm. rendelet) ${ }^{\text {viii }}$ A kormányrendelet iránymutatásainak megfelelően asztalosipari tevékenységet, lakatosipari tevékenységet, festést, felületkezelési tevékenységet, drótfonatkészítést, kerékpár utak, Kanizsa Bike dokkoló állomás takarítását, tisztántartását, közterületek tisztántartását és üvegházi munkát végeztek a programba kerülők.

A programban résztvevők statisztikai adatait elemezve a kor szerinti megoszlást tekintve a 25 év alattiak száma 0 fö. Ezzel szemben az 50 év felettiek száma 36 fö, ez a korcsoport meghatározó a jelen foglalkoztatásban, mivel az összlétszám 53 \%-át teszi ki létszámuk. A 40 és 49 év közöttiek száma 21, amely az összlétszám 30\%-át jelenti, számukra nagyon fontos a munkalehetőség megtalálása. A programból kilépők kor szerinti vizsgálatát tekintve nem találunk kiugróan magas adatot, itt a legmagasabb értéket az 55 év felettiek alkotják (1.táblázat).

1. táblázat. A szolgáltatás célcsoportja. (Forrás:a Szerzö)

\begin{tabular}{|l|r|r|r|}
\hline \multicolumn{1}{|c|}{ Kor } & Létszám(fö) & \multicolumn{1}{c|}{ Programból kilépők száma (fö) } \\
\hline 25 év alatt & 0 & 3 \\
\hline $25-29$ év & 1 & 1 \\
\hline $30-34$ év & 6 & 2 \\
\hline $35-39$ év & 4 & 6 \\
\hline $40-44$ év & 7 & 5 \\
\hline $45-49$ év & 14 & 5 \\
\hline $50-54$ év & 12 & 7 \\
\hline 55 év felett & 24 & 8 \\
\hline Összesen & 68 & 37 \\
\hline
\end{tabular}

Az iskolai végzettség tekintetében jelentős azok száma, akik az általános iskolát sem fejezték be, számuk 13 fö, a teljes létszám 19 \%-át jelenti, amely jelentősen hátráltatja a későbbi foglalkoztatásukat is. Esetükben lehetőség a normál nyolc órás foglalkoztatásba történő átvétel, illetve a nyolc osztály befejezését segítő felzárkóztató tanfolyami képzés jelentheti a továbblépés lehetőségét (2.táblázat). 
2.táblázat: Iskolai végzettség szerinti besorolás (forrás: a Szerzö)

\begin{tabular}{|l|r|r|}
\hline \multicolumn{1}{|c|}{ Végzettség típusa } & Létszám (fö) & Programból kilépők létszáma (fö) \\
\hline Általános iskolai végzettség nélkül & 13 & 9 \\
\hline Általános iskolai végzettség & 33 & 11 \\
\hline Szakiskola & 4 & 4 \\
\hline Szakmunkásképző & 16 & 8 \\
\hline Szakközépiskola & 2 & 4 \\
\hline Technikum & 0 & 1 \\
\hline Gimnázium & 0 & 0 \\
\hline Főiskola & 0 & 0 \\
\hline Egyetem & 0 & 0 \\
\hline Összesen & 68 & 37 \\
\hline
\end{tabular}

Tapasztalataink szerint egy, illetve két osztály megszerzését viszonylag könnyen vállalják az érintett személyek, azonban ennél több osztály hiányzása esetén elzárkóznak a képzés lehetősége elött. A bevonásra kerültek többségét, a program $49 \%$-át, 33 fö az általános iskolát végzettek alkotják. Szakmával 16 fö rendelkezik, a bevontak $23 \%$-át jelenti. Azonban fontos esetükben megjegyezni, hogy sok esetben a megszerzett képesítés munkaerő piaci szempontból elavult, vagy az egészségi állapotuk nem teszi lehetővé számukra a szakmájukban való munkavégzést. A programból kilépők esetében szintén a legmagasabb 11 fö azoknak a száma, akik általános iskolai végzettséggel rendelkeznek, és esetükben is elmondható, hogy szintén magas az általános iskolát be nem fejezettek létszáma is, 9 fö. ( 2 . táblázat)

A programba kerüléskor felmérésre került a regisztrált álláskeresők száma is, ez 60 föt jelentett, minimum 24 hónapja, azaz tartós álláskeresőnek 24 személy vallotta magát, míg arra a kérdésre, hogy a családban legalább 2 fő regisztrált álláskereső van, 21 személy adott pozitív választ. A programból kilépők tekintetében elmondható, hogy ahol a családban legalább két fő a regisztrált álláskereső egy családban, csak egy fö jogosult a foglalkoztatást helyettesítő támogatás igénylésére, így ezen személyek esetében elsődleges szempont a minél magasabb jövedelem szerzés biztosítása. 1990. évi LXV. törvény 7. ${ }^{\text {ix }}$,1997. évi LXXXIII. törvény 83 . $\S^{\mathrm{x}}$ (3. táblázat).

3.táblázat: Munkaerö piaci státusz a programba kerülés elött (forrás: a Szerzö)

\begin{tabular}{|l|r|r|}
\hline \multicolumn{1}{|c|}{ Státusz } & $\begin{array}{c}\text { Létszám } \\
\text { (fö) }\end{array}$ & \multicolumn{2}{c|}{$\begin{array}{c}\text { Programból kilépők } \\
\text { létszáma (fó) }\end{array}$} \\
\hline Regisztrált álláskereső & 38 & 42 \\
\hline Minimum 24 hónapja tartós álláskereső & 20 & 11 \\
\hline A családban legalább 2 fö regisztrált álláskereső van & 10 & 37 \\
\hline Összesen & 68 & \\
\hline
\end{tabular}

A programba kerüléskor felmérésre került a regisztrált álláskeresők száma is, ez 60 föt jelentett, minimum 24 hónapja, azaz tartós álláskeresőnek 24 személy vallotta magát, míg arra a kérdésre, hogy a családban legalább 2 fö regisztrált álláskereső van, 21 személy adott pozitív választ. A programból kilépők tekintetében elmondható, hogy ahol a családban 
legalább két fő a regisztrált álláskereső egy családban, csak egy fö jogosult a foglalkoztatást helyettesítő támogatás igénylésére, így ezen személyek esetében elsődleges szempont a minél magasabb jövedelem szerzés biztosítása. 1990. évi LXV. törvény 7. ${ }^{\mathrm{xi}}, 1997$. évi LXXXIII. törvény 83 . $\S^{x i i}$ (lásd: 3 . táblázat)

A nemek összetételét nézve jelentős a férfiak többsége, eléri a $43 \%$-ot. A 68 főből 39 férfi került bevonásra, ez a teljes létszám $57 \%$-át jelenti. A nemek összetételét az is jelentősen befolyásolja, hogy az egyik munkáltatónál többségében férfiak alkalmazását lehetővé tevő munkafeladatok kerültek kialakításra. A programból kilépettek esetében jóval magasabb a férfiak távozásának aránya. Ennek oka, hogy fizikai munkavégzést biztosító lehetőséget a térségben jóval könnyebben találnak a férfiak, mint a nők.(lásd: 4.táblázat)

4.táblázat. A programban résztvevö személyek nemek szerinti összetétele (forrás: a Szerzö)

\begin{tabular}{|l|l|l|}
\hline Nemek & Összesen (fó) & Programból kilépők száma (fö) \\
\hline Nő & 29 & 10 \\
\hline Férfi & 39 & 27 \\
\hline Összesen & 68 & 37 \\
\hline
\end{tabular}

\section{Módszerek és eszközök}

\section{A mintaválasztás sajátosságai, a minta jellemzői}

A vizsgálatot a Zala megyében megvalósuló Pilot kísérleti programba bevonásra kerülő személyek körében végeztük. A minta összetétele így adott volt, összesen 105 fö került a mintába. A bevonásra került személyek esetében a válaszadás önkéntes volt, a papír-ceruza alapú kérdőívek havonta a mentori szakmai beszámoló részeként, minden személyre vonatkozóan kitöltésre kerültek. Ezeket az adatlapokat alapul véve vizsgáltuk a programba bevonásra került személyek esetében az egyes hónapokra vonatkozóan felmerült problémákat, az életminőség, megélhetéssel, anyagi háttérrel, családi háttérrel, egészségügyi, mentális problémákkal, munkavégzéshez kötődő problémákkal, szociális szolgáltatások igénybevételeivel, egészségügyi szolgáltatások igénybevételével kapcsolatos változásait. Az adatlap itemeire egy ötfokú Likert-skálán történt a válaszadás (jelentösen javult $=5$, részben javult $=4$, nem változott $=3$, romlott $=2$, jelentősen romlott $=1$. Az adatlap kitöltése során a mentoroknak a munkavállalók életminőségének változását kellett kifejezni. Átszámoltuk a Likert skálán kapott eredményeket, ha nem történt változás a vizsgált változók tekintetében 0 , ha javulás történt, a javulás mértékétöl függően 1,2 értéket kapott, ha romlás következett be, a romlás mértékétől függően $-1,-2$ értéket kapott. A kapott eredményeket összesítettük, majd ezekből átlagot számolva kaptuk az eredményeket.

\section{Munkavégzéshez kötődö problémák}

A programba bevonásra került személyek esetében lekérdezést végeztünk arra vonatkozóan mikor volt az utolsó nyílt munkaerő piaci munkaviszony? 
5.táblázat. Utolsó nyilt munkaerö piaci munkaviszony (forrás: a Szerzö)

\begin{tabular}{|l|c|}
\hline \multicolumn{1}{|c|}{ Év } & Személyek száma (fö) \\
\hline nem volt munkaviszonya & 14 \\
\hline $1990-2000$ & 12 \\
\hline $2001-2010$ & 69 \\
\hline $2011-2015$ & 9 \\
\hline 2016 után & 1 \\
\hline Összesen & 105 \\
\hline
\end{tabular}

Az 5. táblázat mutatja be, hogy 14 fö egyáltalán nem rendelkezik nyílt munkaerő piaci tapasztalattal, 12 személy, utoljára 16 évvel ezelött dolgozott a versenyszférában, míg a legtöbb személy, számuk 69 több mint hat évvel ezelőtt dolgozott nyílt munkaerő piacon. Megélhetésüket segélyek, rövidebb-hosszabb közfoglalkoztatási-, alkalmi, illetve „fekete” munka biztosította.

\section{1. ábra. Igazolatlan távollétek száma (forrás: a Szerzö)}

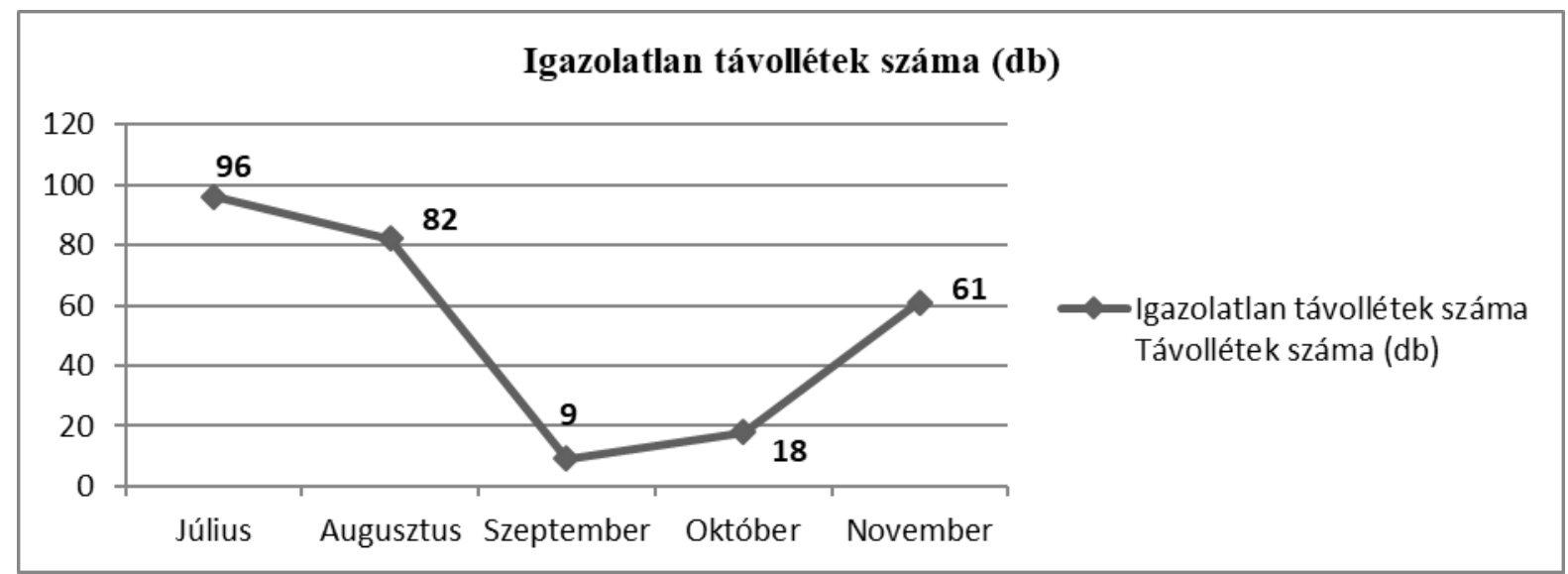

A program öt hónapja során monitoroztuk a munkavégzéshez kötődő magatartásbeli problémák változását valamint a munkavégző képesség változását az igénybevett egészségügyi szolgáltatások számán keresztül. Szeptemberben a magatartásbeli problémák tekintetében az igazolatlan távollétek számát alapul véve, látható, hogy július és hónapokban volt a legmagasabb az igazolatlan hiányzások száma, annak ellenére, hogy a munkáltatók törekedtek arra, hogy elsősorban a szabadságok kerüljenek kiadásra távollét esetén. (1.ábra) Meg kell azonban jegyezni, hogy a nyári hónapokban könnyü viszonylag jól fizető alkalmi munkát találni, ami jóval magasabb bevételi forrást jelent a pilot programban kapott jövedelemnél, illetve ha valaki a munkavállalók közül ittas állapotban jelent meg a munkanap kezdetén, vagy a nap folyamán ittas állapotba került (mivel az esetek többségében külterületeken végeztek az érintett személyek munkát, gyakran felügyelet nélkül, több esetben előfordult, hogy nap folyamán kerültek ittas állapotba), igazolatlannak tekintették az adott napot. Az igazolatlan hiányzások száma szeptember és október hónapokban jelentősen vissza esett, pozitív változást tapasztaltunk, majd a program utolsó harmadában ismét emelkedő tendenciát tapasztaltunk. Ennek hátterében egyrészt az áll, hogy erre az időszakra általában 
elfogytak a szabadságok, illetve erre az időszakra realizálódott egyes személyek tekintetében a továbbfoglalkoztatás lehetősége. Azon személyek esetében, akik számára a munkáltató nem jelezte a továbbfoglalkoztatási szándékot, a munkamorál jelentős mértékben negatív irányba változott. Meg kell azonban jegyezni egyes személyek esetében a magatartásbeli problémák, konfliktus munkavállaló-munkavállaló, munkavállaló-munkáltató között, a program egésze alatt jellemzőek voltak. A munkavégző képesség változását az egészségügyi szolgáltatások igénybevételén keresztül vizsgáltuk, kiugróan magas igénybevételt mutat minden hónapban a háziorvosi-alapellátás igénybevétele összesen 109 esetben, majd ezt követi a különböző szakrendelésekre irányítások száma, amely az öt hónap során összesen 58 alkalommal valósult meg. A pszichiátria szakrendelésen egy esetben, klinikai és mentálhigiénés szakrendelésen öt alkalommal történt megjelenés. Az aktív, valamint a krónikus ellátás igénybevételeinek száma ehhez viszonyítva az egy-egy esettel elenyészőnek mondható.

\section{Fluktuáció}

A munkavégzést jelentősen befolyásolja a fluktuáció, ezért kimutatást végeztünk a programba bevonásra került személyek esetében a fluktuáció mértékéről és annak okáról.(2.ábra, 6. táblázat).

6.táblázat: Fluktuáció (forrás: a Szerző)

\begin{tabular}{|l|r|r|r|r|r|}
\hline \multicolumn{1}{|c|}{ kilépés okai } & július & augusztus & szeptember & október & november \\
\hline egészségügyi orvosi alkalmatlanság & 4 & 0 & 1 & 0 & 0 \\
\hline igazolatlan távollét & 9 & 3 & 0 & 1 & 1 \\
\hline $\begin{array}{l}\text { nyolc órás közfoglalkoztatásba } \\
\text { átvétel }\end{array}$ & 2 & 0 & & & \\
\hline költözés & 0 & 0 & 0 & 3 & 1 \\
\hline nyílt munkaerö-piac & 1 & 4 & 2 & 1 & 0 \\
\hline halál & 1 & 0 & 0 & 0 & 0 \\
\hline ápolási díj & 0 & 2 & 0 & 0 & 0 \\
\hline Összesen & 17 & 9 & 3 & 6 & 2 \\
\hline
\end{tabular}

2.ábra: Fluktuáció (forrás:Szerzö)

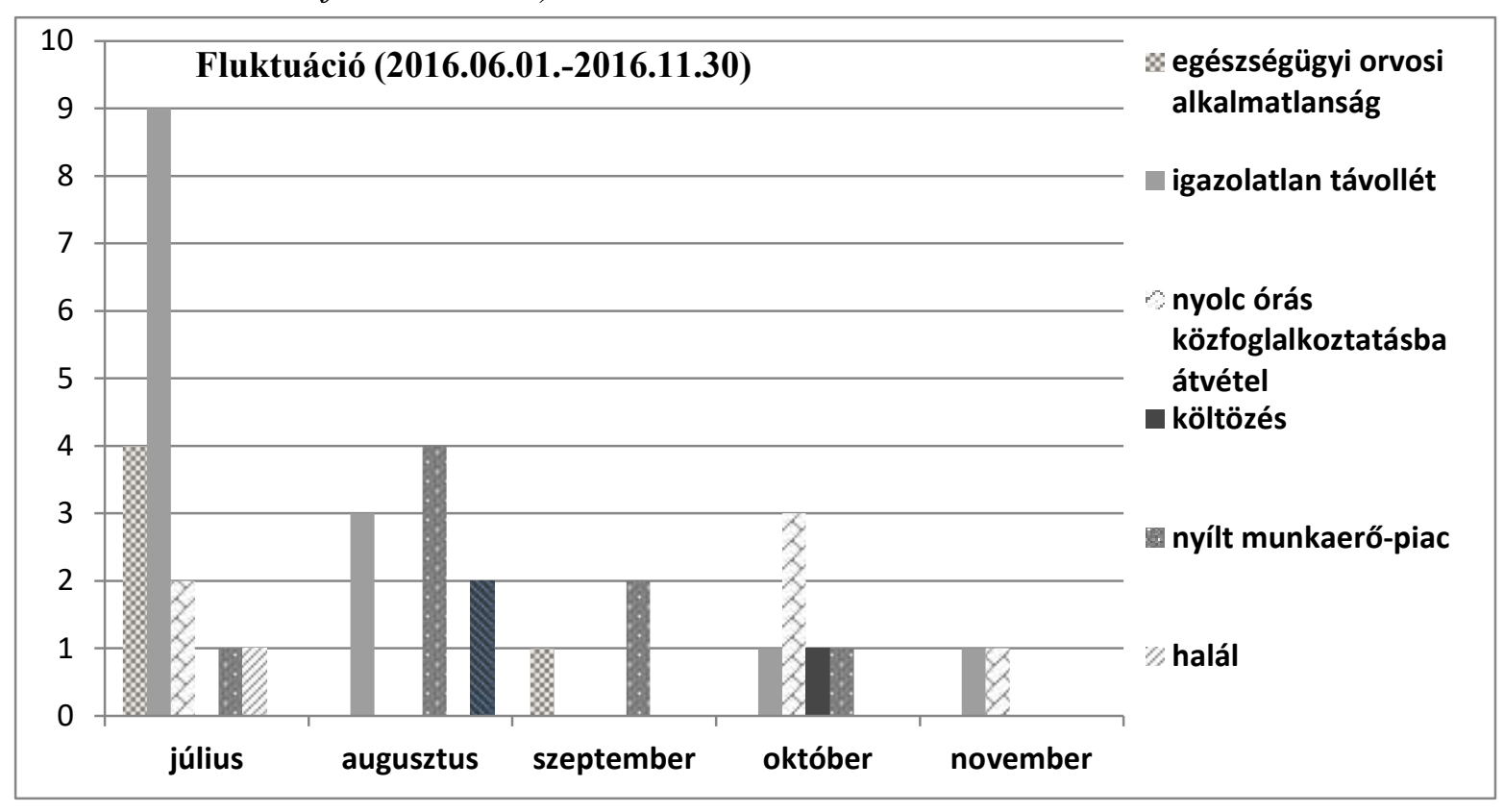


A munkavégzést jelentősen befolyásolja a fluktuáció, ezért kimutatást végeztünk a programba bevonásra került személyek esetében a fluktuáció mértékéröl és annak okáról (2.ábra) A foglalkoztatás kapcsán a fluktuáció tekintetében meghatározó a programba bevonásra kerültek száma, a programot elhagyók száma, illetve a programot befejezettek száma. A pályázati kiírás a két munkáltatónál összesen 75 fő foglalkoztatását tűzte ki célul, melynek megvalósulásaként a programba bevonásra kerültek létszáma 105 fö volt, a programot elhagyók száma 37 fö. A program elhagyásának okai a következők: Az egészségügyi alkalmassági vizsgálat során 11 személy kapott alkalmatlan minősítést. Egy fő a program során elhalálozott, további egy fő egészségügyi állapota olyan mértékben rosszabbodott, hogy a programban történő munkavégzést nem tudta a továbbiakban vállalni. 11 személy esetében az igazolatlan hiányzások következtében a munkáltató által történt a munkaviszony megszüntetésre. Hozzátartozó miatti ápolási díjat három személy igényelt és a továbbiakban nem vett részt a programban. Szintén három személy munkaviszonya közös megegyezéssel szűnt meg. A fluktuációt jelentős mértékben csökkentené a jelen juttatási rendszer továbbgondolása, illetőleg a munkában maradást elősegítené az is, ha a programot befejezők számára a nyolc órás közfoglalkoztatáson kívül több alternatíva, lehetőség lenne a továbbfoglalkoztatásra, hosszabb távú tervezésre.

\section{A változók leiró statisztikai jellemzése}

A vizsgált változók összefüggéseit feltáró statisztikai elemzések elött, az egyes mérőeszközök esetében normalitásvizsgálatot végeztünk. Kolmogorov-Smirnov teszttel igazoltuk, hogy a változók (étkezés, ruházkodás, lakhatás, eladósodottság, kommunikációs képesség, megjelenés, külső rendezettség, addiktológiai probléma, függőség, nehézség hivatalos ügyeinek intézésében,önállótlanság tájékozatlanság, egészségügyi probléma tartós orvosi kezelés alatt áll vagy arra szüksége lenne, családi párkapcsolati probléma, gyermek nevelés, válás, általános mentális személyiségbeli problémák, kiskorú gyermek elhelyezésének problémája idős hozzátartozó elhelyezésének problémája, fogyatékkal élő hozzátartozó elhelyezésének problémája, közlekedési eljutási nehézségek munkahelyre, magatartásbeli problémák, negatív munkavállalói attitüd, alapkészségek nehézségek írásban olvasásban, kommunikációban, munkavégző képesség, együttmüködési képesség,csoportba beilleszkedési készség) nem normál eloszlást követnek ( $\mathrm{p}<001$ minden esetben), ezért Mann Whitney U próbát, valamint Spearman-féle rangkorrelációt számoltunk minden változó esetében. Az idős hozzátartozó elhelyezésének, a kiskorú gyermek elhelyezésének, fogyatékkal élő hozzátartozó elhelyezésének problémáját az öt hónapban vizsgáltuk, a statisztikai elemzéseket elvégeztük, azonban mivel a vizsgált minta tekintetében nem relevánsak a fent említett problémák, ezért a további elemzéseknél ezeket nem vettük figyelembe. A statisztikai elemzéseket az IBM SPSS Statistics 21.0 program segítségével végeztük. Az eredményeket $\mathrm{p}<0,05$ esetén tekintettük szignifikánsnak.

\section{Eredmények}

A korrelációs összefüggések alapján elmondható, hogy néhány változó sok másik változó javulását is eredményezheti. A szignifikáns kapcsolatok mindegyike egyenes irányú, tehát egy változó esetében a javulás a másik változónál is javulást, a csökkenés pedig csökkenést eredményez. A ruházkodás-külső megjelenés, rendezettség közötti összefüggés iránya az elvártnak megfelelő, minél inkább javul a ruházkodás, annál inkább javul a külső megjelenés is. $\left(\mathrm{r}_{\mathrm{s}}: 0,298, \mathrm{p}=0,013\right) \mathrm{Az}$ additológiai probléma javulása sok tényező javulását eredményezi a korrelációs kapcsolatokat vizsgálva. Ennek megfelelően levonhatjuk azt a következtetést, hogyha az additológiai problémában javulást tapasztalunk, akkor az erőteljesen pozitív irányba befolyásolja az együttmüködési képességet, csoportba beilleszkedési készséget, 
$\left(\mathrm{r}_{\mathrm{s}}=0,496, \mathrm{p}=0,000\right)$ az egészségügyi problémák megjelenését, $\left(\mathrm{r}_{\mathrm{s}}=0,342, \mathrm{p}=0,004\right)$ az alapkészségeket, $\left(r_{s}=0,585, p=0,000\right)$ a kommunikációs képességet, $\left(r_{s}=0,614, p=0,000\right)$, a külső megjelenést, külső rendezettséget, $\left(\mathrm{r}_{\mathrm{s}}=0,257, \mathrm{p}=0,035\right)$. A korrelációs kapcsolatokat továbbvizsgálva láthatjuk, hogy az eladósodottság mértékének csökkenésével javulnak a lakhatással kapcsolatos mutatók $\left(\mathrm{r}_{\mathrm{s}}=0,278, \mathrm{p}=0,022\right)$, és pozitív hatással van az általános mentális állapotra is. $\left(\mathrm{r}_{\mathrm{s}}=0,296, \mathrm{p}=0,014\right)$. A kommunikációs képességek javulása javítja az együttmüködési képességet, csoportba beilleszkedési készséget $\left(\mathrm{r}_{\mathrm{s}}=0,659, \mathrm{p}=0,000\right)$ és természetesen az alapkészséget is rendkívül pozitív irányban befolyásolja $\left(r_{s}=0,803, p=0,000\right)$. A megjelenés, külső rendezettség korrelál a kommunikációs képességekkel $\left(r_{s}=0,339\right.$, $\mathrm{p}=0,010)$ valamint az egészségügyi problémák javulásával is. $\left(\mathrm{r}_{\mathrm{s}}=0,319, \mathrm{p}=0,008\right) . \mathrm{Az}$ egészségügyi problémák sok tényezőre hatással vannak, ezek közül a legnagyobb korrelációs kapcsolat a ruházkodással $\left(\mathrm{r}_{\mathrm{s}}=0,381, \mathrm{p}=0,001\right)$, a már említett additológiai problémával, valamint az alapkészségekkel $\left(\mathrm{r}_{\mathrm{s}}=0,297, \mathrm{p}=0,014\right)$, a kommunikációs képességekkel $\left(r_{s}=0,308, p=0,011\right)$ és a külső megjelenéssel kapcsolatban is $\left(r_{s}=0,319, p=0,008\right)$ korrelációs összefüggést fedezhetünk fel. A magatartásbeli problémák eröteljesen meghatározzák a személyek munkavégző képességét $\left(\mathrm{r}_{\mathrm{s}}=0,423, \mathrm{p}=0.000\right)$, kommunikációs képességeit is $\left(\mathrm{r}_{\mathrm{s}}=0,298, \mathrm{p}=0,014\right)$. Az alapkészségek javulása esetén elörelépést tapasztaltunk az együttmüködési képességben, csoportba illeszkedésben $\left(\mathrm{r}_{\mathrm{s}}=0,767, \mathrm{p}=0,000\right)$, valamint a kommunikációs készségben $\left(\mathrm{r}_{\mathrm{s}}=0,803, \mathrm{p}=0,000\right)$, hatására a magatartásbeli problémák, negatív munkavállalói attitüd is javult $\left(\mathrm{r}_{\mathrm{s}}=0,304, \mathrm{p}=0,012\right)$. Az együttmüködési képesség, csoportba beilleszkedés jelentős javulást eredményez a munkavégző képességben $\left(\mathrm{r}_{\mathrm{s}}=0,370\right.$, $\mathrm{p}=0,000)$, magatartásbeli problémákban $\left(\mathrm{r}_{\mathrm{s}}=0,370, \mathrm{p}=0,000\right)$, kommunikációban $\left(\mathrm{r}_{\mathrm{s}}=0,659\right.$, $\mathrm{p}=0,000)$, a hivatalos ügyek intézésével $\left(\mathrm{r}_{\mathrm{s}}=0,284, \mathrm{p}=0,019\right)$, alapkészségek javulásával $\left(r_{s}=0,767, p=0,000\right)$. is összefüggésbe hozható. A program megvalósítási idejét tekintve, július és november hónap eredményeit vizsgálva szignifikáns különbséget tapasztaltunk az étkezés $(\mathrm{p}<0,001)$, a kommunikációs képesség $(\mathrm{p}<0,001)$, az additológiai probléma $(\mathrm{p}<0,001)$, az egészségügyi probléma $(\mathrm{p}=0,004)$, a családi- párkapcsolati probléma $(\mathrm{p}<0,001)$, az idös hozzátartozó elhelyezésének problémája $(p=0,007)$ a közlekedési, eljutási nehézségek a munkahelyre $(\mathrm{p}=0,048)$, alapkészségek $(\mathrm{p}<0,001)$, valamint az együttmüködési képesség, csoportba illeszkedési készségek $(\mathrm{p}<0,001)$ esetében.

Megvitatás: A jóllétnek mind a munkavállalók szubjektív érzelmi átéléseire, mind munkahelyi teljesítményükre pozitív hatása van, ezért a társadalomnak érdemes kiemelt figyelmet fordítania a munkáltatók érzékenyítésére, a komplex támogatási csomagot biztosító programok kialakítására, a munkavállalók életminőségének javulását meghatározó munkahelyi tényezők biztosítására.

\section{Élet a program után}

14 fő a program befejezését követően képzésben vett részt, 5 föt a program ideje alatt vett át a munkáltató nyolc órás közfoglalkoztatott állományba, 17 fö pedig a program végén került átsorolásra. Hat fö a program befejezését követően nyílt munkaeröpiacon talált munkalehetőséget, majd az utókövetés szakaszában további öt fö helyezkedett el sikeresen a nyílt munkaerőpiacon. A program munkavégzéshez kötődő fázisa 2016. november 30-án lezárult, majd december 31-ig utókövetési szakasz keretében tartottuk a kapcsolatot a programba bevonásra került személyekkel. Ebben az időszakban került kitöltésre egy kérdőív, melyben többek között a programhoz kötődő szolgáltatásokkal kapcsolatosan arra kértük a kérdőívet kitöltőket, hogy emeljék ki a véleményük szerint leginkább pozitív tartalommal bíró szolgáltatási elemeket. 
A kitöltés eredményeként a legtöbbször, 22 esetben került kiemelésre az ügyintézések segítése, melyet 21 alkalommal az étkezés, majd 20 alkalommal a mentori illetve az orvosi segítségnyújtás igénybevétele követte. 9 alkalommal történt kiemelésre a munkalehetöség, míg 4 alkalommal az információhoz jutás lehetősége.(7.táblázat)

7. táblázat. A program során a résztvevök által kiemelt szolgáltatások. (forrás: a Szerzö).

\begin{tabular}{|l|r|}
\hline \multicolumn{1}{|c|}{ Szolgáltatások } & db \\
\hline Étkezés & 21 \\
\hline Információ & 4 \\
\hline Ügyintézés & 22 \\
\hline Munkalehetőség & 9 \\
\hline Orvos & 20 \\
\hline Mentor & 20 \\
\hline
\end{tabular}

A kérdőív során megkérdezésre került az is, választási lehetőségeket kínálva hogy, melyek azok az elemek amelyek leginkább hiányoznak a program befejezését követően. A kapott válaszok alapján a leginkább hiányzó elemként a hasznosság érzését emelték ki 40 esetben, míg 34 esetben a rendszeres meleg étkezést jelölték meg. Aki meghallgatott, segített 30 alkalommal került megjelölésre, 28 alkalommal a munkatársak hiányát jelölték meg, 21 alkalommal a munka, feladat hiányzik leginkább, 13 esetben a napi rendszeresség, 3 megjelölést a melegben voltam lehetőség kapott, míg a sort 2 kiemeléssel a kiszámíthatóság, tervezhetőség zárta. A munkaruha hiánya nem került megjelölésre a válaszadások során.(8.táblázat)

8.táblázat: Mi az ami leginkább hiányzik Önnek a program befejezését követöen?(forrás: a Szerzö)

\begin{tabular}{|l|r|}
\hline \multicolumn{1}{|c|}{ Programelem } & Alkalom (db) \\
\hline Napi rendszeresség & 13 \\
\hline Rendszeres meleg étkezés & 34 \\
\hline Hasznosság érzése & 40 \\
\hline Munkatársak & 28 \\
\hline Munka, feladat & 21 \\
\hline Melegben voltam & 3 \\
\hline Kiszámíthatóság, tervezhetőség & 2 \\
\hline Munkaruha & 0 \\
\hline Aki meghallgatott, segített & 30 \\
\hline
\end{tabular}

\section{Következtetés}

Sok esetben az orvosi alkalmassági vizsgálaton a munkavégzésre alkalmatlannak minősített személyek esetében és a tanácsadások során feltárásra került, az előzetes orvosi diagnózisok és az elmondottak alapján indokolt lenne a megváltozott munkaképesség megállapítását meghatározó eljárás elindítása. Azonban a pénzbeli ellátás csak meghatározott munkaviszony leigazolását követően kerül megállapításra, így ezek az emberek csak az egészségkárosodási és gyermekfelügyeleti támogatásra szerezhetnek jogosultságot amelynek összege 
jövedelemmel nem rendelkező egyedül élő személy esetében az öregségi nyugdíj mindenkori legkisebb összegének (2017-ben 28.500 Ft) $92 \%$-a, 2016-ban 26.220 Ft.

Munkavégzés esetén az ellátást szüneteltetni kell. (62/2006. (III. 27.) Korm. rendelet az egyes pénzbeli szociális ellátások elszámolásának szabályairól. ${ }^{x i i}$ Az ügyfelek esetében fontosnak tartom leírni, hogy a program kezdetekor meglehetősen negatív volt a hozzáállásuk, passzivitás jellemezte a résztvevők többségét. Nagyfokú bizalmatlanság jellemezte a csoport nagy részét, nem hittek a segítő szándékunk valódiságában, ezért a program elején kapott háttér információk a program elörehaladtával egyes esetekben nagymértékben változtak. Ezek visszavezethetők többek között a korábbi negatív tapasztalatokra, a programba kerülés idején jellemző szociális helyzetre. A problémáikról is némely esetben jóval később, a bizalmi kapcsolat megszilárdulását követően számoltak be.

Több esetben felderítésre került nagymértékü adósság: Tb nem fizetés, lakbérhátralék, közüzemi számlák hátraléka, egyéb adósságok. A tartós munkanélküliség miatt, sokaknál jelentősen leépült a munkavégző képesség, és számos esetben a szociális készségekre is elmondható ugyanez. Az egyéni beszélgetések során a szociális helyzetfelméréshez a kérdésekre adott válaszok nem mindig helytállóak. Nem tudják megmondani hány év munkaviszonnyal rendelkeznek, milyen jellegü foglalkoztatásban dolgoztak utoljára és mikor. Az ellátások neveit összekeverik. A kezdeti nehézségek közé tartozott, az alapvető közösségi szabályok tisztázása és betartásának elősegítése, a társadalmi és a munkahely, munkavégzés szempontjából szükséges normák betartása. Azonban az idő előrehaladtával ezek egyre kevesebb személynél jelentkeztek, a munkavégzéshez szükséges kompetenciák kialakultak, a társadalmi normák egyre inkább beépültek a mindennapokba.

Kisebb konfliktusok a program egésze alatt elöfordultak, azonban ezek csoporton belül rendezésre kerültek, a sikeres megoldás elősegítette a csoportok összekovácsolódását, amelyet aztán többen meg is jegyeztek a résztvevő személyek közül. Ez fontos momentuma, mérföldköve volt ennek a néhány hónapnak, hiszen a biztonságérzetükre, önbecsülésükre, ezáltal teljesítményükre is pozitívan hatott. Az állandóság, ami a munkafolyamatokat jellemezte, sikerélményekkel gazdagította a dolgozókat és pozitív irányba mozdította el a személyiségüket. A támogatásokkal kapcsolatos ügyintézésben sok segítséget nyújtottak a mentorok, ezzel hozzájárulva a szociális háttér javításához. A programban lévő munkavállalók az ügyintézésekkel kapcsolatban és a hétköznapi életben is magabiztosabbá váltak. Néhányan a későbbiekben igyekeztek egyedül elintézni az ügyeiket, az önálló ügyintézésre való törekvésüket ösztönöztük is a program során, azonban egyes személyek esetében megállapítható, hogy mentális állapotuk sajnos nem teszi ezt lehetővé. A pilot speciális közfoglalkoztatási programba kerülő személyek hátterével, problémáival kapcsolatosan már az előzetes tanácsadások során is szembesültünk, hogy mennyire komplexek, sokrétüek és szerteágazók. Néhány személytől eltekintve családi hátterük rendezetlen, az elmúlt évtizedek foglalkoztatáspolitikájának következményeként a társadalom szélén lévő, kirekesztett személyekről van szó. Elmondható, hogy abszolút mértékben a túlélésre rendezkedtek be. Életvitelüket a távlati perspektíva teljes hiánya jellemzi, naprólnapra történő terveznek, amelynek megoldására sajnos ez a program sem képes, azonban úgy vélem, hogy számos alapvető probléma és a továbbiakban továbbgondolásra alapot nyújtó információ került rögzítésre.

Azok az ügyfelek, akik ténylegesen valamilyen egészségügyi problémával küzdenek és emiatt nem tudtak elhelyezkedni, pozitívan értékelték a lehetőséget, ez megmutatkozott a munkafegyelemben, a szabályok betartásában. Azok, akik nem küzdenek egészségügyi problémával és eddig ellátásuk is volt (Foglalkoztatást helyettesítő támogatás), kevésbé motiváltak az alacsony bér miatt. Néhány személy számára az öt hónap is jelentős előrelépést jelentett, mind az anyagiak terén, mind pedig a szociális helyzetük terén, ez föként azokra igaz, akik a programba kerülést megelőzően nem részesültek ellátásban. Azok, azonban akik 
programba kerülésük előtt foglalkoztatást helyettesítő támogatásban részesültek, rendkívül kevésnek tartották a kapott juttatást, mely néhány ezer forinttal haladta meg a segélyt. Esetükben szélmalomharcnak bizonyult az érvelésünk, mely szerint nő a munkaviszonyban eltöltött idő, kapnak étkezést, számos plusz juttatást (segélyeket) igényeltünk, a program továbblépési lehetőség a foglalkoztatás szempontjából. Szemben állt ezzel a foglalkoztatottak perspektívája, mely szerint az ismerőseik „kiröhögik” őket, amiért ennyi pénzért dolgoznak, nem tudnak elmenni „maszekba”. A társadalmi környezet, amelyből érkeztek, nagymértékben befolyásolta és hatott a munkavégzésükre, munkamoráljukra is.

A speciális közfoglalkoztatási program végéhez közeledve, kétoldalú megállapodás keretében kiválasztásra kerültek azok a személyek, akiket a munkáltatók a program befejezése után is alkalmazni kívántak. Ez fordulópontot jelentett, mivel a résztvevők közül néhányan nehezen fogadták el a program végét, és azt, hogy számukra véget ér a foglalkoztatás. Ez egyesekből negatív érzéseket váltott ki, kétségbeesést, csalódottságot és elkeseredést tapasztalhatunk annak ellenére is, hogy az egyéni és csoportos tájékoztatások keretében is ismertetésre kerültek az aktuális munka- és tanfolyami lehetőségek. Felajánlottuk a segítségnyújtást a munkahelykereséshez, önéletrajzokat készítettünk, valamint felajánlottuk a továbbiakban történő kapcsolattartást. Az alkoholfogyasztás problémájának felerösödése valószínüleg ez miatt is ismételten előtérbe került. A program elején tapasztalt negatív világnézet és kilátástalanság, fóként a depresszióra hajlamos egyéneknél egyre inkább felerősödött.

A kérdöív által összegzett eredményekből jól látszik, hogy legtöbb alkalommal került kiemelésre a hasznosság érzésének hiánya a program befejezését követően, szintén magas a meleg étkezés hiányának megemlítése és ezek mellett kiemelném a munkatársak valamint a munkavégzés, feladat hiányának megemlítését. A programba bevonásra került személyek legalább 12 hónapja nem dolgoztak a bevonás előtt az eredményekből azonban jól látszik, hogy már az öt hónap is elégnek bizonyult annak tekintetében, hogy a hasznosan töltött idő, a rendszeresség, és a munkakapcsolatok hiányozzanak a résztvevők életéből. Még a foglalkoztatók által továbbfoglalkoztatottak esetében is indokoltnak tartanánk a program keretében biztosított egy hónap utókövetésen túli, hosszabb távú mentális segítségnyújtást, támogatást.

Szükségét éreznénk, egy a speciális és normál közfoglalkoztatás között megvalósuló programnak, vagy esetlegesen néhány személy esetében a mentori szolgáltatás hosszabb távú biztosításának, ezzel mintegy biztosítva, hogy a program végére valamennyi ügyfél, ha akarja, akkor kapja meg a lehetőséget a továbblépésre. Az azonban a célcsoport tekintetében megjegyzendő, a jelen programba bevonásra került személyek egy részére jellemző, hogy reális esélye a továbbfoglalkoztatásuknak csak speciális közfoglalkoztatásban képes hosszabb távon megvalósulni. A kapcsolattartással próbáljuk elérni, hogy azok, akik kikerülnek a programból, ne sodródjanak, ne szakadjanak el a társadalomtól. Itt azonban megjegyeznénk, hogy meglátásunk és eddigi tapasztalatunk szerint ezt a munkát hatékonyan végezni csak olyan személy képes, aki stabil, pozitív és támogató személyiséggel rendelkezik. Hitelesen azonban meglehetősen nehéz úgy jövőképet kialakítani és formálni, hogy a segítő szakember maga is teljesen bizonytalan a saját jövőbeli foglalkoztatottságát illetően. Véleményünk szerint többféle alternatíva is létezhet a probléma megoldására, egyik ilyen megoldás lehetne a pilot program, mint első lépcsőfok, melyből továbblépési lehetőség lenne a normál közfoglalkoztatás vagy valós munkaerő piaci igényeknek megfelelő átképzés lehetősége, melyet követhetne a továbbfoglalkoztatás vagy egyéb elsődleges munka eröpiaci reintegráció lehetősége, melyet a munkáltatói oldal felöl esetleges bértámogatással, egyéb kedvezményekkel ösztönözve lehetne biztosítani. A meghatározott célok elérése érdekében azonban elengedhetetlen a programban résztvevők közös, együttes és összehangolt munkája. 


\section{Konklúziók}

Összességében megállapítható, hogy jelentős aktivitást eredményezett a munkanélküliek között a pilot program elindítása, sok szempontból mentális javulást is teremtett az új munkahelyi környezet, az új közösség, a tanácsadások során feltárásra kerültek a továbblépés lehetőségét biztosító megoldási alternatívák. A program pozitív hatása a foglalkoztatási helyzet javításában is megmutatkozott, hiszen a bevont személyek közül a tanácsadások és a mentor segítségnyújtás következményeként több résztvevő a versenyszférába, helyi önkormányzatok foglalkoztatásába, valamint közmunka programokba is felvételre került. A program bebizonyította azt is, hogy fellelhetök olyan hátrányos helyzetü, nehezebb sorsú emberek, akik bár segítséggel és irányítással, de visszavezethetők a munka világába. Azok az emberek is lehetöséget kaptak a speciális program által, akik az elsődleges munkaerő piacon, sőt még a hagyományos közfoglalkoztatás keretében sem lennének képesek átmenetileg, vagy tartósan munkavégzésre, másrészt olyan rétegek is bevonásra kerültek a programba, akik eddig minimálisan, vagy egyáltalán nem dolgoztak semmilyen formában. Bár a közfoglalkoztatás gyakran képezi vita tárgyát a politikai közbeszédben, azonban számos esetben ez az egyetlen lehetősége a kiúttalan, jövőtlen embereknek, hogy hasznosnak érezhessék magukat és kapcsolódni tudjanak a saját közegük mindennapi életébe. A pilot speciális közfoglalkoztatási programban résztvevő közfoglalkoztatottak a közös teherviselés mellett részt vehettek azokban a mindennapi szokványos élethelyzetekben is, hogy van kötelezettségük, fel kell kelniük reggel, el kell menniük dolgozni.

\section{Jogszabályok}

1040/2016. (II.11.) Kormány határozat, a közfoglalkoztatás 2016. évi céljairól és a közfoglalkoztatás szempontjából kiemelt települések meghatározásáról 2.d) (2016.06. 08.)

Web: http://www.kormány.hu (Letöltés:2016.07. 01.)

1991. évi IV. törvény a foglalkoztatás elősegítéséröl és a munkanélküliek ellátásáról 40.§ (2016.07.10.)

Kötelező egészségbiztosítás ellátásairól szóló 1997. évi LXXXIII. törvény (2016.11.05.)

217/1997. (XII.1.) Kormány rendelet a kötelező egészségbiztosítás ellátásairól szóló 1997. évi LXXXIII. törvény végrehajtásáról (2016.11.05.)

1253/2016.(VI.6.) Kormány határozat a mentális, szociális vagy egészségügyi okból foglalkoztatásba be nem vonható álláskeresők foglalkoztathatóságának növelését szolgáló 2016. évi kormányzati intézkedésekről (2016.11.14.)

170/2011.(VIII.24.) Kormány rendelet a közfoglalkoztatási bér és a közfoglalkoztatási garantált bér megállapításáról (2016.11.23.)

375/2010.(XII.31.) Kormány rendelet a közfoglalkoztatáshoz nyújtható támogatásokról (2016.11.23.)

1990. évi LXV. törvény a helyi önkormányzatokról 7. § (2016.11.23.)

1997. évi LXXXIII. törvény a kötelező egészségbiztosítás ellátásairól 83. § (2016.11.05.)

(62/2006. (iii. 27.) Kormány rendelet az egyes pénzbeli szociális ellátások elszámolásának szabályairól.(2016.07.10.) 